University of Nebraska - Lincoln

DigitalCommons@University of Nebraska - Lincoln

Growth and Feed Efficiency of Juvenile Channel Catfish Reared at Different Water Temperatures and Fed Diets Containing Various Levels of Fish Meal

\author{
Menghe H. Li \\ Mississippi State University, mli@drec.msstate.edu \\ Edwin H. Robinson \\ Mississippi State University \\ Brian C. Peterson \\ United States Department of Agriculture \\ Terry D. Bates \\ United States Department of Agriculture
}

Follow this and additional works at: https://digitalcommons.unl.edu/usdaarsfacpub

Part of the Agricultural Science Commons

Li, Menghe H.; Robinson, Edwin H.; Peterson, Brian C.; and Bates, Terry D., "Growth and Feed Efficiency of Juvenile Channel Catfish Reared at Different Water Temperatures and Fed Diets Containing Various Levels of Fish Meal" (2008). Publications from USDA-ARS / UNL Faculty. 579.

https://digitalcommons.unl.edu/usdaarsfacpub/579

This Article is brought to you for free and open access by the U.S. Department of Agriculture: Agricultural Research Service, Lincoln, Nebraska at DigitalCommons@University of Nebraska - Lincoln. It has been accepted for inclusion in Publications from USDA-ARS / UNL Faculty by an authorized administrator of DigitalCommons@University of Nebraska - Lincoln. 


\title{
Growth and Feed Efficiency of Juvenile Channel Catfish Reared at Different Water Temperatures and Fed Diets Containing Various Levels of Fish Meal
}

\author{
Menghe H. Li* and Edwin H. Robinson \\ Thad Cochran National Warmwater Aquaculture Center, Mississippi State University, \\ Post Office Box 197, Stoneville, Mississippi 38776, USA
}

\author{
Brian C. Peterson and Terry D. Bates
}

U.S. Department of Agriculture, Agricultural Research Service, Catfish Genetics Research Unit, Thad Cochran National Warmwater Aquaculture Center, Post Office Box 38, Stoneville, Mississippi 38776, USA

\begin{abstract}
Channel catfish Ictalurus punctatus do not feed well at low temperatures. It is generally thought that a diet containing fish meal enhances feed palatability at low temperatures since fish meal is highly palatable to fish. There is a lack of information on the effects of fish meal levels on the growth performance of channel catfish reared at low temperatures. Therefore, a study was conducted in a recirculating system to examine the effects of fish meal levels on the feed consumption, weight gain, and feed efficiency of juvenile channel catfish reared at various temperatures. Fish with an initial weight of $9.6 \pm 0.1$ $\mathrm{g}$ were stocked in $23-\mathrm{L}$ clear polycarbonate tanks maintained at approximately 17,21 , or $27^{\circ} \mathrm{C}$. The fish were fed with diets containing 0, 4, or $8 \%$ menhaden Brevoortia spp. fish meal for 9 weeks. There was a significant interaction between water temperature and fish meal level with respect to weight gain. At $27^{\circ} \mathrm{C}$, fish fed diets containing $4 \%$ and $8 \%$ fish meal gained significantly more weight than fish fed the all-plantprotein diet. However, the level of fish meal had no significant effect on the weight gain of fish at $17^{\circ} \mathrm{C}$ or $21^{\circ} \mathrm{C}$. This suggests that the olfactory and gustatory responses of channel catfish to fish meal (up to $8 \%$ in the diet) may not be as sensitive at low temperatures as at optimum temperatures. The results also indicate that more than $4 \%$ fish meal in the diet is not beneficial for the optimum growth and feed efficiency of channel catfish fingerlings raised at $27^{\circ} \mathrm{C}$.
\end{abstract}

Unlike warm-blooded animals, channel catfish Ictalurus punctatus do not feed consistently when water temperatures are below $20^{\circ} \mathrm{C}$ and generally stop eating at temperatures of $10^{\circ} \mathrm{C}$ (Robinson et al. 2004). Many catfish producers choose not to feed during winter months for various reasons, one of which is that it is difficult to see a positive response from a winter feeding program. However, based on research results, winter feeding is beneficial, though the magnitude of benefit from a winter feeding program depends on the severity of winter. Fish will gain (if fed) or lose (if not fed) more weight during a mild winter than during a cold one. A recent study conducted at Delta Western Research Center, Indianola, Mississippi (E. H. Robinson, unpublished data), as well as research by Lovell (1989), has shown that food-sized channel catfish gain $15-18 \%$ of their body weight during a mild winter (average daytime water temperatures from November 15 to March 15 were about $11-13^{\circ} \mathrm{C}$ ). Fingerlings were shown to gain up to $45 \%$ (Lovell 1989) if they were fed during the winter.

\footnotetext{
* Corresponding author: mli@drec.msstate.edu
}

Received August 23, 2007; accepted October 16, 2007 Published online June 2, 2008
Because the feeding activity of channel catfish is reduced at low temperatures, it is hypothesized that adding a highly palatable feedstuff, such as fish meal, to the diet would increase feed consumption by catfish at low temperatures. There have been anecdotal reports that channel catfish eat more feed at low temperature when they were fed diets containing fish meal; however, this has not been scientifically validated. There are several reports on the effects of dietary fish meal levels on growth and feed efficiency of channel catfish fingerlings and food fish raised during the growing season or at optimum water temperatures, but results are inconsistent. Some studies show that complete removal of fish meal in the diet reduces fish growth (Andrews and Page 1974; Mohsen and Lovell 1990; Robinson and $\mathrm{Li}$ 1998; $\mathrm{Li}$ et al. 2006). In contrast, other reports indicate that nutritionally balanced all-plant diets can provide similar growth and feed efficiency as diets containing fish meal (Webster et al. 1992; Robinson and Li 1994; Reigh 1999; Li et al. 2003). The objective of the present study was to evaluate effects of dietary fish meal level on feed consumption, weight gain, and feed efficiency of channel catfish at various water temperatures. 
TABLE 1.- Ingredient and proximate composition of experimental diets (percent as fed).

\begin{tabular}{|c|c|c|c|}
\hline \multirow[b]{2}{*}{ Ingredient } & \multicolumn{3}{|c|}{ Fish meal content $(\%)$} \\
\hline & 0 & 4 & 8 \\
\hline Soybean meal $(48 \%)^{\mathrm{a}}$ & 42.90 & 37.44 & 31.99 \\
\hline Cottonseed meal $(41 \%)^{\mathrm{a}}$ & 5.00 & 5.00 & 5.00 \\
\hline Menhaden fish meal $(61 \%)^{a}$ & 0.00 & 4.00 & 8.00 \\
\hline Corn grain (extrusion-cooked) & 31.63 & 33.88 & 36.12 \\
\hline Wheat middlings & 15.00 & 15.00 & 15.00 \\
\hline Dicalcium phosphate & 1.15 & 0.68 & 0.20 \\
\hline $\mathrm{C}$-free vitamin $\operatorname{mix}^{\mathrm{b}}$ & 0.05 & 0.05 & 0.05 \\
\hline Vitamin $\mathrm{C}^{\mathrm{c}}$ & 0.05 & 0.05 & 0.05 \\
\hline Trace mineral mix ${ }^{\mathrm{b}}$ & 0.10 & 0.10 & 0.10 \\
\hline Carboxymethylcellulose & 2.00 & 2.00 & 2.00 \\
\hline Catfish offal oil & 2.12 & 1.81 & 1.50 \\
\hline Digestible energy (DE; kcal/g) ${ }^{\mathrm{d}}$ & 2.72 & 2.74 & 2.76 \\
\hline Digestible protein (DP; \% $)^{\mathrm{d}}$ & 23.4 & 23.2 & 23.1 \\
\hline $\mathrm{DE}: \mathrm{DP}$ ratio $(\mathrm{kcal} / \mathrm{g})$ & 11.6 & 11.8 & 12.0 \\
\hline \multicolumn{4}{|l|}{ Proximate composition $(\%)^{\mathrm{e}}$} \\
\hline Crude protein & $27.56 \pm 0.15$ & $27.29 \pm 0.05$ & $27.49 \pm 0.20$ \\
\hline Crude fat & $3.39 \pm 0.00$ & $3.61 \pm 0.01$ & $3.61 \pm 0.01$ \\
\hline Ash & $5.40 \pm 0.08$ & $5.57 \pm 0.06$ & $5.64 \pm 0.03$ \\
\hline
\end{tabular}

\footnotetext{
${ }^{a}$ The numbers in parentheses represent the percentages of crude protein.

${ }^{\mathrm{b}}$ See Robinson et al. (2001).

${ }^{\mathrm{c}}$ Provided by L-ascorbyl-2-monophosphate (35\% activity).

${ }^{\mathrm{d}}$ Estimated from tabular values of Robinson et al. (2001).

e Values are mean $\pm \mathrm{SD}(90 \%$ dry-matter basis; $n=2)$.
}

\section{Methods}

Three $28 \%$-protein, practical diets (Table 1) were formulated to contain 0, 4, or $8 \%$ menhaden Brevoortia spp. fish meal with digestible energy to digestible protein ratios (DE:DP) of $11.6-12.0 \mathrm{kcal} / \mathrm{g}$ protein. All known nutrient requirements of channel catfish were satisfied (NRC 1993). The diets were prepared as sinking pellets according to procedures described previously ( $\mathrm{Li}$ et al. 1993) and stored at $-30{ }^{\circ} \mathrm{C}$ until used. The menhaden fish meal (regular grade) was obtained from Omega Protein, Inc. (Hammond, Louisiana). Other feed ingredients were obtained from the Delta Western Feed Mill (Indianola, Mississippi) and were from commercial sources. The proximate composition of diet samples (Table 1) was analyzed by standard methods (AOAC 2000). Specifically, dietary protein levels were determined by the combustion method with an FP-2000 protein determinator (Leco Corporation, St. Joseph, Michigan), crude fat by ether extraction with a Soxtec System (Foss North America, Eden Prairie, Minnesota), dry matter by oven drying with a mechanical convection oven (Precision, Winchester, Virginia), and ash with a muffle furnace (Type 30400; Barnstead Thermolyne Corporation, Dubuque, Iowa).

Juvenile channel catfish of the NWAC103 strain were reared in indoor tanks in a common environment $\left(12 \mathrm{~h}\right.$ light : $12 \mathrm{~h}$ dark; water temperature $=26.5^{\circ} \mathrm{C} ; \mathrm{pH}$ $=8.6$; and dissolved oxygen $>5.0 \mathrm{mg} / \mathrm{L}$ ) under common management and feeding conditions at the
U.S. Department of Agriculture-Agricultural Research Service (USDA-ARS) Catfish Genetics Research Unit, Stoneville, Mississippi, before stocking into the aquarium rack systems. Three X-rack aquarium rack systems (Model $\mathrm{XR}_{3}$; Marine Biotech, Beverly, Massachusetts) were used in the study. Each system was configured with sixteen 23-L clear polycarbonate tanks. Each tank had a polycarbonate lid with access holes for feeding and water and air inlets. Each tank was supplied with individual water and air valves, air stones, and rear-side, midtank drains with removable mesh screens to prevent feed loss. Water flow rate to each tank was maintained at a rate higher than $500 \mathrm{~mL} /$ min via an adjustable flow regulator.

Three-stage particulate filtration was used that included a $150-\mu \mathrm{m}$ reusable polyester filter pad, chemical filtration via activated carbon, and a mechanical pleated cartridge filter. Biofiltration was accomplished by passing water through a submerged silica gravel bed in the reservoir tank. Two of the rack systems were connected to separate $90-\mathrm{kW}$ air-cooled water chillers with a single, six-cylinder Copeland compressor (Copeland Corporation, Sidney, Ohio). Fish were acclimated to the colder temperatures by reducing the temperature $2^{\circ} \mathrm{C} / \mathrm{d}$ until the targeted temperatures $\left(20^{\circ} \mathrm{C}\right.$ and $\left.15^{\circ} \mathrm{C}\right)$ were obtained. The temperatures in the three rack systems were $26.9 \pm$ $0.1,21.0 \pm 0.2$, and $16.6 \pm 0.4^{\circ} \mathrm{C}$, respectively, during the feeding period. Water quality tests for ammonia and nitrite were monitored twice a week, 
while dissolved oxygen (DO) was measured by use of a Model 58 DO meter (YSI, Yellow Springs, Ohio) once a week. Ammonia and nitrite were maintained below 0.025 and $0.1 \mathrm{mg} / \mathrm{L}$, respectively, while DO levels were maintained above $7 \mathrm{mg} / \mathrm{L}$.

Before initiation of the experiment, 20 fish were stocked in each tank and acclimated to the experimental conditions for 2 weeks and fed diet 2 once daily to apparent satiation at 0900 hours. After acclimation, fish in each temperature group were pooled and graded into a uniform size, and 10 fish were restocked in each tank. Initial fish weight averaged $9.6 \pm 0.1 \mathrm{~g} /$ fish. Four tanks were assigned to each diet $\times$ water temperature combination. All fish were fed once daily as much as they would eat within 60 min to ensure that fish were satiated. The total feed consumption was recorded daily. Fish were counted and weighed collectively (by tank) every 3 weeks. At the end of week 9, feed consumption and weight gain per fish, feed efficiency ([ total final fish weight - total initial fish weight $\}+$ weight of mortalities removed]/total feed consumption), and survival were determined.

Data were subjected to two-way analysis of variance (ANOVA), and means were subsequently separated via Fisher's protected least-significant-difference procedure (Steel et al. 1997) in Statistical Analysis System (SAS) version 8.0 (SAS Institute 2004). Survival data were square-root transformed before ANOVA was performed. Tanks were used as experimental units. A significant level of 0.05 was used.

\section{Results and Discussion}

The 9-week growth curve indicated that water temperature and dietary fish meal significantly affected fish weight as early as week 3 (Figure 1). Feed consumption at the end of week 9 was markedly affected by water temperatures but not by dietary fish meal level and water temperature $\times$ fish meal interaction (Table 2). Fish survival was not affected by water temperature, fish meal level, or their interaction. However, there was a significant interaction between water temperature and fish meal level for weight gain. While no significant differences were observed in weight gain of fish fed diets containing three levels of fish meal at $17^{\circ} \mathrm{C}$ and $21^{\circ} \mathrm{C}$, respectively, at $27{ }^{\circ} \mathrm{C}$ fish fed diets containing $4 \%$ and $8 \%$ fish meal gained significantly more weight than fish fed the all-plant-protein diet. This is contrary to what we originally thought (i.e., that channel catfish might respond better to a diet containing fish meal at low temperatures). At $17^{\circ} \mathrm{C}$ and $21^{\circ} \mathrm{C}$, fish meal levels up to $8 \%$ did not affect weight gain of juvenile channel catfish, which suggests that the olfactory and gustatory responses of channel catfish to fish meal (up to $8 \%$ in

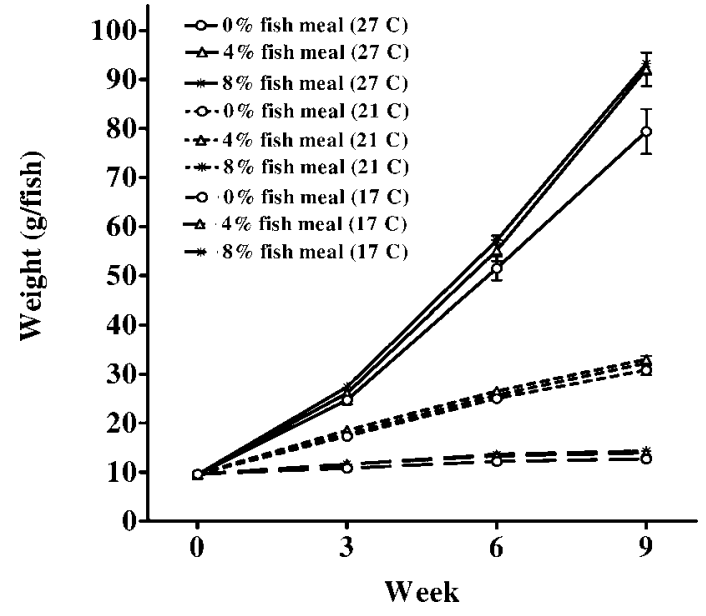

FIGURE 1.-Fish weights at weeks 3, 6, and 9 as affected by water temperature and the fish meal level of the diets. At weeks 3 and 6, there were no significant interactions between water temperature and dietary fish meal level. Regardless of fish meal level, fish weights were significantly different among the three water temperatures. Regardless of water temperature, fish fed an all-plant diet gained less weight than fish fed fish meal diets. At week 9, a significant interaction was observed for weight gain (see Table 2 for details).

the diet) may not be as sensitive at low temperatures. Although there were no significant differences in feed consumption of fish fed the three levels of fish meal, at $27^{\circ} \mathrm{C}$ feed consumption tended to be slightly higher in fish fed the diets containing fish meal, which resulted in a significant difference in weight gain.

Published results on the effects of fish meal level on the growth of channel catfish fingerlings and food fish at optimum water temperatures have been inconsistent and often contradictory. For pond-raised, food-sized channel catfish, some studies showed that fish meal could be eliminated in the diet without affecting fish growth (Robinson and Li 1994; Reigh 1999), while others reported a growth reduction when all-plantprotein diets were used (Robinson and Li 1998). In addition, we recently conducted additional studies that indicated that fish meal improved weight gain of channel catfish (no other animal protein was used in the diet). Similarly, some studies with fingerlings cultured in aquaria demonstrated a need for fish meal for maximum growth (Andrews and Page 1974; Mohsen and Lovell 1990; Li et al. 2006), but others did not (Webster et al. 1992; Li et al. 2003). The reason for the contrasting results from different studies is not clear but could be caused by differences in the quality of fish meal and other ingredients used, feeding rates, culture conditions, and other unidentified factors. In the present study, fish were fed once daily, a feeding 
TABLE 2.-Mean feed consumption, weight gain, feed efficiency, and survival of channel catfish fed practical diets containing various levels of fish meal in recirculating systems at various water temperatures for 9 weeks.

\begin{tabular}{|c|c|c|c|c|c|}
\hline Variable & $\begin{array}{l}\text { Fish meal } \\
\text { level }(\%)\end{array}$ & $\begin{array}{l}\text { Feed consumption }{ }^{\mathrm{a}} \\
\text { (g/fish) }\end{array}$ & $\begin{array}{l}\text { Weight gain }{ }^{\mathrm{b}} \\
\text { (g/fish) }\end{array}$ & $\begin{array}{l}\text { Feed efficiency } \\
\quad \text { (gain/feed) }\end{array}$ & $\begin{array}{l}\text { Survival } \\
(\%)\end{array}$ \\
\hline \multicolumn{6}{|c|}{ Individual treatment means ${ }^{\mathrm{c}}$} \\
\hline \multicolumn{6}{|l|}{ Temperature $\left({ }^{\circ} \mathrm{C}\right)$} \\
\hline 17 & 0 & 12.5 & $3.1 \mathrm{w}$ & $0.249 \mathrm{w}$ & 97.5 \\
\hline 17 & 4 & 13.6 & $4.4 \mathrm{w}$ & $0.324 \mathrm{x}$ & 97.5 \\
\hline 17 & 8 & 14.2 & $4.8 \mathrm{w}$ & $0.331 \mathrm{x}$ & 100.0 \\
\hline 21 & 0 & 41.1 & $21.2 \mathrm{x}$ & $0.515 \mathrm{y}$ & 100.0 \\
\hline 21 & 4 & 43.0 & $23.4 \mathrm{x}$ & $0.545 \mathrm{y}$ & 97.5 \\
\hline 21 & 8 & 40.2 & $22.7 x$ & $0.563 \mathrm{zy}$ & 97.5 \\
\hline 27 & 0 & 113.9 & $69.9 \mathrm{y}$ & $0.612 \mathrm{zy}$ & 100.0 \\
\hline 27 & 4 & 123.3 & $82.5 \mathrm{z}$ & $0.669 \mathrm{zy}$ & 97.5 \\
\hline 27 & 8 & 122.7 & $83.7 \mathrm{z}$ & $0.682 \mathrm{z}$ & 100.0 \\
\hline Pooled SE & & 2.6 & 2.1 & 0.014 & 1.9 \\
\hline \multicolumn{6}{|c|}{ Means of main effect ${ }^{d}$} \\
\hline \multicolumn{6}{|l|}{ Temperature $\left({ }^{\circ} \mathrm{C}\right)$} \\
\hline 17 & & $13.4 \mathrm{r}$ & 4.1 & 0.301 & 98.3 \\
\hline 21 & & $41.4 \mathrm{q}$ & 22.4 & 0.541 & 98.3 \\
\hline 27 & & $120.0 \mathrm{p}$ & 78.7 & 0.654 & 99.2 \\
\hline & 0 & 55.8 & 31.4 & 0.459 & 99.2 \\
\hline & 4 & 60.0 & 36.8 & 0.513 & 97.5 \\
\hline & 8 & 59.0 & 37.1 & 0.525 & 99.2 \\
\hline \multicolumn{6}{|c|}{ ANOVA: $P$-values } \\
\hline Temperature & & $<0.001$ & $<0.001$ & $<0.001$ & 0.82 \\
\hline Fish meal & & 0.16 & 0.005 & $<0.001$ & 0.46 \\
\hline Temperature $\times$ fish meal & & 0.34 & 0.025 & 0.011 & 0.74 \\
\hline \multicolumn{6}{|c|}{$\begin{array}{l}\text { a Feed consumption was on a } 90 \% \text { dry-matter basis. } \\
\text { be Initial weight was } 9.6 \pm 0.1 \mathrm{~g} \text { fish (mean } \pm \mathrm{SD}, n=36 \text { ). There were no significant differences } \\
\text { among treatments (ANOVA: } P>0.05 \text { ). }\end{array}$} \\
\hline \multicolumn{6}{|c|}{$\begin{array}{l}\text { Treatment means represent the average values of four tanks per treatment. Fisher's protected least- } \\
\text { significant-difference procedure was conducted for individual means only if there was a significant } \\
\text { interaction (ANOVA: } P \leq 0.05 \text { ). Means followed by the same letter are not significantly different. } \\
\text { d Main effect means followed by the same letter are not significantly different at } P=0.05 \text { by Fisher's } \\
\text { protected least-significant-difference procedure. }\end{array}$} \\
\hline
\end{tabular}

frequency commonly used during the growing season by the catfish industry. Whether feeding frequency affects fish meal levels in the diet for optimum fish growth is not known.

The highest water temperature used in the present study was $27^{\circ} \mathrm{C}$, which was slightly lower than that used in our previous studies $\left(30^{\circ} \mathrm{C}\right)$ but still within the range of temperatures reported for maximum growth of juvenile channel catfish $\left(27-32^{\circ} \mathrm{C}\right.$; Kilambi et al. 1971; Andrews and Stickney 1972; Buentello et al. 2000). At $27^{\circ} \mathrm{C}$, fish fed $4 \%$ and $8 \%$ fish meal diets gained 18.0 $19.7 \%$ more weight than fish fed the all-plant-protein diet. The difference between the present study and our previous aquarium studies is that in the present study fish were cultured in a recirculating system and were fed more closely to satiation, whereas our previous studies ( $\mathrm{Li}$ et al. 2003, 2006) used a flow-through system in which fish were fed based on percentage of body weight. There is no evidence that culture systems (flow-through versus recirculating system) interact with dietary effects. Since menhaden fish meal is highly palatable to channel catfish, feeding more closely to satiation as was used in the present study would magnify the fish meal effect on fish growth.

Marine fish meals contain higher levels of fat and DE than most plant protein sources; thus, the inclusion of fish meal in the diet may improve fish growth. However, this does not appear to be the case for the present study. The increase in the weight gain of fish fed diets containing 4-8\% fish meal does not appear to be caused by DE content since the diets were formulated to contain similar quantities of fat and DE. This observation is supported by Mohsen and Lovell (1990) who noted that the addition of catfish oil to the all-plant, basal diet to increase the DE content to that of a diet containing $10 \%$ fish meal did not improve weight gain in juvenile channel catfish.

Andrews and Page (1974) attributed the increased weight gain in channel catfish fed fish meal diets to unidentified "growth factors" that were not related to lysine and sulfur-containing amino acids but that were present in the protein fraction of menhaden fish meal. Mohsen and Lovell (1990) suggested that the improved growth in channel catfish fed fish meal diets was 
related to the improved feed palatability of the diet but cautioned that improved palatability may not continue if the fish became adapted to "less palatable" all-plant diets.

In the present study, feed efficiency was affected by water temperature, fish meal level, and their interaction (Table 2). At $17^{\circ} \mathrm{C}$, feed efficiency was significantly higher in fish fed the fish meal diets than fish fed the all-plant-protein diet. However, the improved feed efficiency in fish fed fish meal diets at $17^{\circ} \mathrm{C}$ did not result in significant increase in weight gain. The reason for this is not clear. Although there were significant differences in the weight gain of fish fed various levels of fish meal at $21^{\circ} \mathrm{C}$ and $27^{\circ} \mathrm{C}$, no significant differences in feed efficiency were noted. This could be caused by the variation in amounts of feed offered in excess among tanks. Fish were fed to apparent satiation by visual examination, but the slight excess of feed remained, if any, was not removed from the tank.

For all three fish meal levels, feed efficiency was higher at $21^{\circ} \mathrm{C}$ and $27^{\circ} \mathrm{C}$ than at $17^{\circ} \mathrm{C}$. There was a trend that feed efficiency was higher at $27^{\circ} \mathrm{C}$ than at $21^{\circ} \mathrm{C}$ for the three levels of fish meal, respectively $(P \leq$ 0.085). Generally, feed efficiency decreases when water temperature deviates from the optimum range (24-32 ${ }^{\circ}$ C; Kilambi et al. 1971; Andrews and Stickney 1972; Buentello et al. 2000).

Assuming that fingerling channel catfish need fish meal in their diets for maximum growth at optimum temperatures, the results of the present study and $\mathrm{Li}$ et al. (2006) indicate that $4 \%$ fish meal in the diet is adequate for optimum growth and feed efficiency under the conditions of these studies. Li et al. (2006) reported that fingerlings raised in aquaria and fed allplant-protein diets had about $12-15 \%$ reduction in weight gain compared with fish fed diets containing fish meal (Li et al. 2006), which was about what we observed in the present study. However, it is not known whether the $12-15 \%$ reduction in weight gain among fingerlings raised in aquaria will be realized in ponds because of the natural food present in nursery ponds. In some of our previous studies, we noted only about $5 \%$ reduction in weight gain in food-sized channel catfish raised in ponds and fed all-plant-protein diets (Robinson and $\mathrm{Li}$ 1998; M. H. Li and E. H. Robinson, unpublished data). In addition, because there is concern about fish meal use in aquaculture (i.e., fish meal production from the ocean may threaten wild fish stocks), all-plant-protein diets would be more environmentally friendly. The potential connotations for environmentally friendly diets could enhance marketing of catfish products.

In summary, it appears that fish meal is not an essential component in the diets of juvenile channel catfish reared at low temperatures $\left(17-21^{\circ} \mathrm{C}\right)$. However, at optimum temperatures $\left(27^{\circ} \mathrm{C}\right)$, a reduction in weight gain was noted when an all-plant-protein diet was fed. An $8 \%$ fish meal diet did not further improve the weight gain of fish over a $4 \%$ fish meal diet. Whether fish meal is economical for use in channel catfish feeds depends on its price relative to other plant and animal protein sources that can be used to replace fish meal.

\section{Acknowledgments}

The authors thank Monica Loden, Jimmy Warren, and Reece Mascagni at the USDA-ARS Catfish Genetics Research Unit, and Sandra Phillips, Cliff Smith, and Penny Lucas at the National Warmwater Aquaculture Center for assistance in laboratory management and feeding. This manuscript is approved for publication as journal article J-11184 of the Mississippi Agricultural and Forestry Experiment Station (MAFES), Mississippi State University. This project is supported under MAFES project MIS-371310. Reference to trade names does not imply endorsement by the U.S. Government.

\section{References}

Andrews, J. W., and J. W. Page. 1974. Growth factors in the fish meal component of catfish diets. Journal of Nutrition 104:1091-1096.

Andrews, J. W., and R. R. Stickney. 1972. Interactions of feeding rate and environmental temperature on growth, food conversion, and body composition of channel catfish. Transactions of the American Fisheries Society 101:94-99.

AOAC (Association of Official Analytical Chemists). 2000. Official methods of analysis, 17th edition. AOAC International, Gaithersburg, Maryland.

Buentello, J. A., D. M. Gatlin, III, and W. H. Neill. 2000. Effects of water temperature and dissolved oxygen on daily feed consumption, feed utilization, and growth of channel catfish (Ictalurus punctatus). Aquaculture 182:339-352.

Kilambi, R. V., J. Noble, and C. E. Hoffman. 1971. Influence of temperature and photoperiod on growth, food consumption, and food conversion efficiency of channel catfish. Proceedings of the Annual Conference Southeastern Association of Game and Fish Commissioners 24(1970):519-531.

Li, M. H., M. R. Johnson, and E. H. Robinson. 1993. Elevated dietary vitamin $\mathrm{C}$ concentrations did not improve resistance of channel catfish, Ictalurus punctatus, against Edwardsiella ictaluri infection. Aquaculture 117:303312.

Li, M. H., B. C. Peterson, C. L. Janes, and E. H. Robinson. 2006. Comparison of diets containing various fish meal levels on growth performance, body composition, and insulin-like growth factor-I of juvenile channel catfish Ictalurus punctatus of different strains. Aquaculture 253:628-635. 
Li, M. H., D. J. Wise, B. B. Manning, and E. H. Robinson. 2003. Effect of dietary total protein and animal protein on growth and feed efficiency of channel catfish Ictalurus punctatus and their response to Edwardsiella ictaluri challenge. Journal of the World Aquaculture Society 34:223-228.

Lovell, T. 1989. Nutrition and feeding of fish. Van Nostrand Reinhold, New York.

Mohsen, A. A., and R. T. Lovell. 1990. Partial substitution of soybean meal with animal protein sources in diets for channel catfish. Aquaculture 90:303-311.

NRC (National Research Council). 1993. Nutritional requirements of fish. National Academy Press, Washington, D.C.

Reigh, R. C. 1999. Production characteristics of pond-raised channel catfish Ictalurus punctatus fed diets with and without animal protein for three growing seasons. Journal of the World Aquaculture Society 30:154-160.

Robinson, E. H., and M. H. Li. 1994. Use of plant proteins in catfish feeds: replacement of soybean meal with cottonseed meal and replacement of fish meal with soybean meal and cottonseed meal. Journal of the World Aquaculture Society 25:271-276.

Robinson, E. H., and M. H. Li. 1998. Comparison of practical diets with and without animal protein at various concentrations of dietary protein for performance of channel catfish Ictalurus punctatus raised in earthen ponds. Journal of the World Aquaculture Society 29:273-280.

Robinson, E. H., M. H. Li, and B. B. Manning. 2001. A practical guide to nutrition, feeds, and feeding, 2nd revision. Mississippi Agricultural and Forestry Experiment Station Technical Bulletin 1113.

Robinson, E. H., B. B. Manning, and M. H. Li. 2004. Feeds and feeding practices. Pages 324-348 in C. S. Tucker and J. A. Hargreaves, editors. Biology and culture of channel catfish. Elsevier, Amsterdam.

SAS Institute. 2004. SAS/STAT 9.1 user's guide. SAS Institute, Cary, North Carolina.

Steel, R. G., J. H. Torrie, and D. A. Dickey. 1997. Principles and procedures of statistics. A biometric approach, 3rd edition. McGraw-Hill, New York.

Webster, C. D., J. H. Tidwell, L. S. Goodgame, D. H. Yancey, and L. Mackey. 1992. Use of soybean meal and distillers grains with solubles as partial or total replacement of fish meal in diets for channel catfish, Ictalurus punctatus. Aquaculture 106:301-309. 